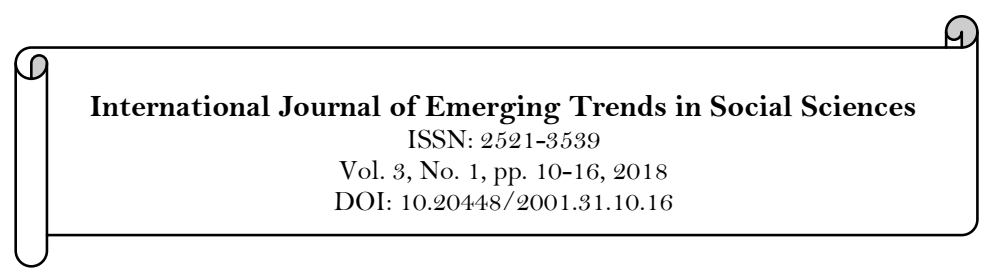

\title{
Scratching an Invisible Limb A Lacanian Reading of Sam Shepard's Buried Child
}

\author{
Nima Behroozi Moghadam ${ }^{1}$ \\ ${ }^{1}$ School of Literature and Humanity Sciences, Shiraz University, Iran. \\ Email:nyma.behrouzy@gmail.com
}

\begin{abstract}
Alienation and loss appear as a pivotal theme in the majority of Sam Shepard's family plays. This study intends to give a Lacanian reading of Sam Shepard's Buried Child. Drawing primarily on Lacan's linguistic theory of psychoanalysis, as well as his definition of psychosis, this study shows how Tilden's alienation in the play stems from the foreclosure of the paternal metaphor in the symbolic registry of the psyche which, consequently, causes a malfunction in the process of oedipalization by leaving a hole in the Other where the Name-of-the-Father, as the metaphor for the law against incest, should appear. As a result, the subject is regressed to the imaginary where he can play the role of the phallus for the mother, which is manifested in the backstory of Buried Child as an act of incest between Tilden and Halie. Further, the incompetence of the father in the play in establishing the law is argued as being a circular curse that goes from generation to another.
\end{abstract}

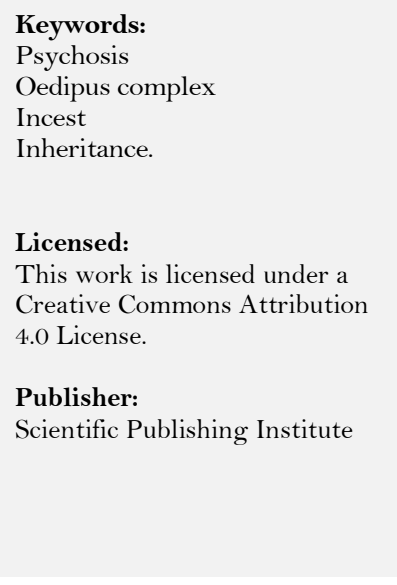

\section{Introduction}

The preoccupation with a fragmented, alienated self finds a powerful expression and constitutes a central theme in the works of the American playwright Sam Shepard. Some have arguably endeavored to explain this dilemma through the postmodern jargon by building on what Jameson (1991) calls "loss of historicity" or "historical deafness" (x) and the break with the past. Clum (2002) for instance, locates this fragmentation in the heart of a masculinity crisis which stems from the absence of and/or detachment from mythic heroes and Western myths. "The sons are compelled," he writes, "to connect with ideals of masculinity for which there are no real models and with myths of the American land that are no longer relevant" (173). As a result, the male figures in Shepard's plays "frequently tread the very edge of insanity" (Bigsby, 2004). They are driven to insanity precisely because, as Shepard himself has said, "the possibility of somehow miraculously making [themselves] into a different person is a hoax, a futile game" (Rosen, 1993).

Focusing on Shepard's Buried Child, the author aims to explain the roots of Tilden's "insanity" through the Lacanian paradigms of psychoanalysis. Plays such as Buried Child are mainly constructed on their characters' emotional states and psyches, and in a way the plot is only secondary. That is, one may be easily tempted to view the homecoming story, around which the whole plot revolves, as (to borrow a cinematic term) a McGuffin: an object/event which gives impetus to the plot but is insignificant in itself. The conflict in the play is not so much in the incidents that are happening in the present moment, but rather in things that have happened before and the traces they have left on the characters' psyches. Accordingly, Buried Child sets to explore, in the context of American agrarian life, the catastrophic situation of the postmodern individual through a nightmarish journey into a family's subconscious. The play, therefore, structurally yields to psychoanalytic approaches in general, and to Lacanian theories in particular.

Shepard's plays are typically characterized by a quest upon which the (male) characters embark to find their identity in a postmodern era where the self has become fragmented and disoriented, as it is the case with Tilden in Buried Child. Following Lacanian psychoanalysis, Tilden's alienation signals signs of psychosis which occurs through the failure of primal repression, namely the foreclosure of the Name-of-the-Father (i.e. the paternal law) as a signifier. This foreclosure is brought about due to what Lacan calls "an accident in the symbolic register" (Écrits 215) which leaves a hole in the other where the Name-of-the-Father should be. Incidentally, the failure of oedipalization and the foreclosure of the gap between subject and object (i.e. the Other) give rise to the subject's fixation upon a narcissistic quest to become the phallus for the mother; hence the incestuous relationship between Tilden and Halie in the backdrop of the play. The subject regresses from the symbolic to the imaginary where castration has never occurred; that is, the subject has not mastered the 
Name-of-the-Father as the symbolic law. He is dominated not by a symbolic father, but by an imaginary one who is in the guise of either an ideal father or, to quote Lacan, a "father... who has fucked the kid up" (The Ethics, 308).

There is a curious condition in medical science known as the "phantom limb": any person who has experienced the amputation of a limb will tell you how they feel the missing limb is still attached to their body and how "it" produces sensations as pain and itching. They will also tell you how in frenzied, desperate attempts, they will scratch the ghost limb, clawing at the air, tearing it apart; this limb that doesn't exist, and this pain that doesn't subside. There is something of a similar nature in Shepard's disillusioned characters who, not being able to cope with the changes and the seeming emptiness that thereby grips the postmodern man, burst out in rage and to frantic violence, or, like Travis in Paris, Texas, just run and run until every sign of man is disappeared.

\section{The Failure of the Paternal Metaphor}

Let us begin with Lacan's most fundamental contribution to the post-Freudian psychoanalysis; namely, that the unconscious is structured like a language. Apropos of Lacan's theory of linguistic nature of the unconscious, it is the play of different signifiers, or more precisely the substitution of one signifier for another, that results in the constitution of the subject as a sexuated being.

For Lacan, as well as for Shepard, loss is a key term. Both view the "disoriented self" as the result of the split between the "subject" and the "ego" (Carveth, 1997). The activity of consciousness, Lacan declares, is "always erratic" and "fragmented" (The Ethics 223). This loss or fragmentation for Lacan and for Shepard as well, is closely connected to and manifested in language: in Lacanian theory, with the child's inscription to the symbolic order there begins an endless chain of signification in which one signifier is always missing - the chain is always incomplete. The "missing signifier", as Lacan puts it, is the subject himself, literally (224). Pivotal in Lacan's theory of subject is the role of the phallus as the signifier of lack in the Oedipus complex, which should be discussed here in both its imaginary and symbolic dimensions.

The Oedipus complex begins at the moment when the child starts to realize that $\mathrm{s} /$ he is no longer the mother's sole object of desire. As the dyad relationship between the child and the mother slowly disintegrates, the phallus, as an imaginary object, substitutes the child as the mother's object of desire. The child inevitably identifies with the phallus in order to return to the former state of union with the mother. That is, through the phallic identification, the child attempts once more to satisfy the mother's desire. As Homer further explains, " $[\mathrm{t}]$ he imaginary phallus is what the child assumes someone must have in order for them to be the object of the mother's desire and, as her desire is usually directed towards the father, it is assumed that he possess the phallus" (55).

Insofar as the child identifies with the phallus as the mother's object of desire, the phallus is imaginary. As the child realizes that $\mathrm{s} /$ he can never be the mother's object of desire, since $\mathrm{s} /$ he assumes the father possesses something that s/he lacks, the phallus plays a symbolic role. In this sense, the Oedipus complex involves "the process of giving up the identification with the imaginary phallus" and recognizing at the same time that the imaginary phallus "is a signifier and as such was never there in the first place" (55). Subsequently, the child substitutes the phallus with another signifier, which Lacan calls the Name-of-the-Father. As the phallus is installed in the symbolic register of the unconscious as the paternal metaphor of the socio-symbolic law, the child effectively becomes a subject in the symbolic order. Thus, it follows that the symbolic father is the agent of law and, more specifically, of prohibition of incest. It should be noted that the symbolic father is not so much a real figure, but a name or a signifier; i.e. the father "dies" and returns as his name to establish his law of prohibition. The paternal function of the phallus is indeed crucial for an understanding of psychosis, but only insofar as the paternal metaphor is symbolic, since for Lacan, "the symbolic Father is, in so far as he signifies this Law, the dead Father" (Écrits 199).

To sum up, the constitution of the normal subject involves the primal repression which in effect sets to motion the process of signification through substitution of signifiers. This is how the subject is effectively inscribed in the symbolic register. At this point, an important question arises: what if something prevents the subject from successfully integrating into the symbolic order? Psychosis is concerned, primarily, with this question. Lacan writes:

For the psychosis to be triggered off, the Name-of-the-Father, verworfen, foreclosed, that is to say, never having attained the place of the Other, must be called into symbolic opposition to the subject. (Écrits 217).

To put the above quotation succinctly, what triggers psychosis - or what prevents the child from becoming a normal subject - is due to what Lacan elsewhere calls "an accident in the symbolic register" which leaves a hole in the Other where the Name-of-the- Father should be. In order to have a better grasp of what Lacan means by this "accident" in the symbolic register, it is essential to understand his distinction between psychosis and neurosis which are defined by the terms "foreclosure" and "repression," respectively. Here Lacan's theory of psychosis differs from that of Freud, in that he initially lays off the idea that a psychotic "represses" the real. For Lacan and Lacanians, it is precisely through the primal repression (i.e. the subscription to the paternal law) that the subject is effectively inserted in the symbolic order. And this is what 
the psychotic has been unable to achieve. Thus, to explain psychosis, Lacan employs the term "foreclosure" which, corresponding to the Freudian term verwerfung (repudiation), designates the exclusion of the phallic signifier and the failure of primal repression.

Foreclosure, by definition, excludes any possibility of repression. Unlike the repressed content, the foreclosed experience cannot be re-evoked again since it has not been symbolized and, therefore, is not caught in the network of discourse. "The impossibility of re-evoking the foreclosed experience," Lemaire explains, "arises from the fact that the psychotic never really had access to the principle of symbolization: one signifier is put in the place of another which it is not" (231). The onset of psychosis, Lacan asserts, is the moment at which, "from the field of the other, there comes the interpellation of an essential signifier that is unable to be received" (Pyschoses 306). Lacan further explains that the failure of oedipalization.

Sets off the cascade of reshapings of the signifier from which increasing disaster of the imaginary proceeds, to the point at which the level is reached at which signifier and signified are stabilized in the delusional metaphor (Écrits 217).

In other words, due to the failure of internalizing the Name-of-the-Father as the signifier of law, not only the psychotic is unable to distinguish between the signifier and the signified which, in effect, precludes him from using language correctly, but also he regresses to the "disaster of the imaginary" where it gives way to his narcissistic fixation to play the role of the phallus for the mother.

\section{The Disaster of the Imaginary}

Having thus provided a context for our critical argument by expanding on a number of the key themes in Lacan's theories of subject and of psychosis, we can now bring to focus how the theories can be applied in our reading of the play.

Tilden is the most alienated character in Buried Child, and signs of his alienation can be appropriately dated back to events occurred well before the actual time of the play when he initially "lost his voice". Early on in the play, while having a dialogue with his alcoholic father Dodge, he recalls his wanderings somewhere in a desert in New Mexico: "I was lonely... I was more lonely that I've ever been before" (71). A good starting point for analyzing Tilden's alienation and his accordingly childish behavior is the way he is treated by other characters of the play. Two major but different influences contribute to Tilden's anomie and personal disintegration: maternal connection and paternal connection. The former is characterized by the act of incest between the mother (Halie) and the son (Tilden) in the past, and also by Halie's treatment of Tilden as an immature child who needs to be looked after, as evident in her dialogue with Dodge where she says, "We have to watch him just like we used to now... He's still a child" (77). The latter is centered upon the pervasive sense of estrangement in Tilden's relationship with Dodge and vice versa, for which our argument is momentarily directed towards Herbert Marcuse's notion of "fatherlessness", i.e. the decline of the father image and the role it plays in the obsolescence of the autonomy of the subject.

The Mirror Stage in Lacan's theory marks a period in the psychic development of the child when the child is blissfully united with its mother. As the child acknowledges the presence of the father as the signifier for its mother's object of desire, the child experience a separation which forever haunts and scars him like an invisible wound. This initial, imaginary fragmentation leaves many a hole in the Other of the subject, which he, while entering the symbolic order, tries to fill with what Lacan calls objet petit a. Now, since for the psychotic the gap between the subject and object is foreclosed, i.e. since he has never mastered the Name-ofthe-Father as the substitution for the phallus, he is hurled back - regresses - to the imaginary where not only he tries, in a narcissistic fashion, to still be the phallus (the object of desire) for the mother by seducing her; but also he is, at once, "exempt" from the social/paternal law against incest.

This is the exact condition we are encountering in Buried Child: the backstory of the incest, which is never directly addressed by any member of the Shepard's family, is strongly emblematic of Tilden's psychosis. Since he has not been symbolically castrated by the "dead" father (Dodge), the mother, as the object of the son's desire, is no longer forbidden. Thus, Tilden is still in a childish quest to be Halie's lover. Similarly, Tilden is still a child for Halie, who needs to be "watched over", whom Halie obsessively yet ineffectually tries to protect like a minor, even from getting wet in the rain. Interestingly enough, Tilden, like a child, has no faculty of language whenever he's fronting with Halie:

HALIE: Dodge, tell Tilden not to go out in the back lot. I don't want him back in the rain.

DODGE: You tell him. He’s sitting right here.

HALIE: He never listens to me... He's still a child. (77).

Central in Tilden's reasons of fragmentation is the role of the maternal attitude. Tilden's failure in primal repression stems from, at least partially, Halie's attitude towards Dodge, from the way Halie looks at the father. She has long ago given up on Dodge, and this can be evidently traced back to a time well before Dodge drowns her and Tilden's son and buries him in the backyard. What she sees in Dodge is simply not a man. Her attitude is one of the main reasons that Dodge is a failed, emasculated patriarchy, which is also ironically the direct result of her betrayal with Tilden, and her constant idealizing of Ansel (her other dead son) whom for her was the only real man: "He was a hero! A man! A whole man!" (124).

Here we can recognize the importance of the maternal attitude in the failure of oedipalization in Lacan's 
theory of psychosis: if the mother "recognizes in the father the function of establishing the rule of the law of societies by respecting his speech," writes Lemaire, the child will find "the name and the place he is destined to occupy in the family constellation" (234). If, however, she treats the child "as the complement of her own lack, as the phallus with which the child is in any case trying to identify... then the child cannot dispose of his own individuality" (234). For Halie, the death of her favorite son Ansel and the impotence of her husband signify an absence for which she inexorably has to find a surrogate in Tilden.

To sum up, the foreclosure of the Name-of-the-Father, as the signifier of law, leads the subject to have a disastrous relation with language. As a consequence, Lacan's famous teaching that the speech is founded in the existence of the Other becomes impaired in the subject's unconscious, since there's a big hole in the Other in the place of the Name-of-the- Father. For the subject, the woman does not exist because "analytic discourse... brings into play the fact that woman will never be taken up except quoad matrem" (qtd. in A Compendium, "Sexuation"). That is to say, in order to be able to write a sexual relation between man and woman, the woman should be taken as the mother, as a forbidden object, that serves her function as the fulfillment of a primal lack. Since the psychotic has never been castrated, women will not be considered as objet petit a to fill the hole of castration.

The symbolic father - not necessarily the real father or even a male figure but "a symbolic position that the child perceives to be the location of the object of the mother's desire" (Homer, 2005) - is the agent of law and, more specifically, of prohibition of incest. The symbolic father is not so much a real figure, but a name - a signifier; the father dies, so to speak, and returns as his name to establish his law of prohibition. The foreclosure of the paternal metaphor triggers psychosis in the child and, consequently, reduces the symbolic father to the imaginary father who, as Lacan tells us, is either the ideal father (as god figures in religions) or the father of primal horde in Freud's Totem and Taboo (who imposes the incest taboo on his sons), and who, nevertheless, in either guise is omnipotent (Evans, 1996). On the imaginary level, Dodge is the ironic embodiment of this omnipotent father in Buried Child.

As the head of the family, Dodge is surrounded by images of impotence: his inertia and his alcoholism indicate his failure as the symbolic father. Furthermore, his impotence has direct relation to the sterility of the land. Through use of folklore and mythology, particularly the ironic allusion to the myth of Osiris and the corn-god, Shepard shows a wasteland in which, just like T. S. Eliot's poem, resurrection brings no renewal. This is also necessary for our argument on the first aspect of the imaginary father.

Frazer (1993) gives numerous accounts of how the ancient people would make human sacrifices in their rituals in order to promote the growth of the crops. The people of Cañar, for example, "used to sacrifice a hundred children annually in their harvest time." Similarly, the ancient Mexicans "sacrificed human beings at all various stages of growth of the maize, the age of the victims corresponding to the age of the corn." (431)

Tilden's act of bringing in corns from the infertile backyard, and Dodge's many pseudo-surrealistic burials under the corn sheaves, establishes a strong link between the play and the myth of Osiris (see also Nash, "The Ironic Use of Folklore"). According to the myth, in one of his aspects god was a personification of the corn. Frazer adds:

[T]he conception of [Osiris] as the corn-god comes clearly out in the festival of his death and resurrection ... The festival appears to have been essentially a festival of sowing... On that occasion an effigy of the corn- god, moulded of earth and corn, was buried with funeral rites in the ground in order that, dying there, he might come to life again with the new crops. (337).

Thus, in the absence of a real father figure, Tilden involves in a ritual to resurrect the "dead" father. Imaginary father is an ideal father, but, nonetheless, he is imaginary - he does not exist. Here the Lacanian distinction between "ideal ego" and "ego ideal" can shed more light on the matter.

The "ideal ego" is construed as an idealized, autonomous image with which the child falsely identifies in the Mirror Stage. On the other hand, the "ego ideal", being "the symbolic foundation of identification", is "something that the ego strives to be but is not" (Pluth, 2007). The ritualistic burials of Dodge signal the tension between these two modes of identification: the imaginary identification and the symbolic identification. On the imaginary level, Dodge is the "ideal ego", an imaginary construction (imaginary father) who, like the father of primal horde, has access to all women, including the mother. This is the main image which Tilden identifies with, and which allows him to become reunited with his mother in an incestuous relationship. On the symbolic level, however, Dodge is the failure of the ego ideal - the other whose gaze the subject (i.e. Tilden) tries to impress. Here, the role of Dodge as the father is that of a signifier which is supposed to permit Tilden to extract himself from it in order to establish a position and a meaning for himself. Pluth adds: "What is important here is the notion that the ego ideal is a signifier in the other from whose 'point of view' the individual is given a meaning and a place” (53).

Tilden's ritualistic performance of burying Dodge under the corn sheaves indicates his desperate attempt to become, once more, integrated into the symbolic order. That is, by murdering his father, Tilden is trying to subvert the regressive entrapment of the imaginary, which, in effect, allows his passage from the animal state to Culture (Žižek, 2007). Regarding the necessity of this parricide, Žižek further adds:

[T] he actual bearer of prohibition, what prevents our access to the incestuous object, is not the living but the dead father who, after his death, returns as his Name, that is, as the embodiment of the 
symbolic Law/Prohibition... [T] he father is elevated into the venerated symbol of Law only after his betrayal and murder (316).

Nevertheless in Buried Child, this rather complex process of identification and murder through the act of corn ritual proves to be futile because the resurrection eventually brings no renewal, for "the new King [i.e. Vince] is as impotent and as unable to bring renewal as the old" (Adler, 2002).

Corresponding to the psychotic's regression to the imaginary and the mother's recognition of the child as the complement of her own lack, the symbolic father reduces to the imaginary father, as already discussed. This reduction for Marcuse is embedded in a condition of fatherlessness which is due to the obsolescence of the father image as the object of identification in the sweeping changes of the advanced industrial societies. Marcuse holds that, in such a society, "[t] he socially necessary repressions and the socially necessary behavior are no longer learned - and internalized - in the long struggle with the father" (47).

To put it succinctly, technical progression - and especially the prevalence of the mass media - in a more advanced society is significantly instrumental in formation of the ego, according to Marcuse. In the absence of a strong father, the child turns to "ideas and facts of life as transmitted by the mass media" (50) to find its way in the world. But it is precisely this freedom from the paternal authority which releases the child from the socially-necessary repressions that shrinks the ego to a weak entity, ill-equipped to become a self with and against others, to offer effective resistance to the powers that now enforce the reality principle, and which are so different from father... but also so very different from the images purveyed by the mass media. (50)

It goes without saying that the ubiquity of the T.V. in all the scenes of the play has certain marks on the characters, which, if weakly corroborates the phenomenon Marcuse is explaining, still has some benefits when it comes to discuss the other dead son, Ansel.

Given that there is a myth in the play surrounding the true identity of Ansel as a genuine war hero and a great basketball player, and since all the family members have their own account of him, it seems reasonable to assume Halie, who is negotiating with a local priest for putting up a memorial statute of Ansel for his achievements, has taken her idealized image of her dead son from an external source - namely, the T.V. which, as far as we are concerned in the play, is showing baseball games. This idea can be reinforced by Dodge's reference to Pee Wee Reese as he's watching television: Reese was a ten-time All-Star who won seven National League championships for the Dodgers. For Halie, the only similarity that her husband and Reese (as a hero and as a man) bear in common is Dodge's baseball cap. And in complementing her lack, she has to fabricate lies about her son to make up for Dodge's symbolic absence. Also, Dodge's insistence on keeping his baseball cap is ironical both in the sense that he is identifying with masculine figures of sport that he is not, and a fear that his son Bradley, or otherwise Halie, is trying to castrate him by "cutting" his hair and leaving him bald. Therefore not only Dodge is a failure as a patriarch, he is also, in a wider sense, the failure of the American Dream - for both of which Halie needs to compensate through idealizing her dead son (which also echoes in the mind of the reader the theme of incest and suggests the circularity of it in the context of the play). Just as Travis in Paris, Texas tries to find an ideal father image for his son by searching magazines and practicing before a mirror (Carveth, 1997) here, the ideal masculine figure is an image, or images, that someone takes, albeit unconsciously, from television and mass media.

\section{A Sea of Language}

In a fatherless society, Marcuse adds, and in line with the decline of father as the image of authority, "a tremendous release of destructive energy would occur" which "lead [s] to the collapse of the group" (53). Although Marcuse believes that this is not yet our historical situation, the aforementioned aggressiveness is evident and rampant at the core of the play, tearing the family apart: the backstory entails a violent crime committed by Tilden, the details of which nobody knows; Bradley is abusive both in speech and manner when he cuts Dodge's hair violently, and when he forces his finger into Shelly's mouth; in an ironic turn, his amputated leg becomes a defensive weapon with which Shelly attacks him etc. Like other Shepard's plays, Buried Child is full of tension and violence, in which the characters are sadistically fighting for their dominance. But the real violence, as Bigsby notes, "is an internal pressure which threatens to implode character, dissemble it along lines of primitive fears, needs and desires" (Modern Drama 166). Opipari (2010) locates the roots of this violence in the incest and the family's loyalty in keeping it a secret, and observes that the incest "creates shame so powerful that the system almost completely shuts down, devoid of meaningful communication" (124).

Shepard's family in the play has been paralyzed by the subsequent feeling of shame engendered by the act of incest. All the members of the family have fallen into and are trapped in dysfunctional behavior loops that preclude or distort any act of genuine communication. This introduce a paradox in the context of the play: the family is both the source of comfort and of pain; although the family members are constantly neglecting or escaping from each other, they, at the same time, need someone to protect them and hear them. As a result, their speech is marked by ill conversational styles and their manner as lewd. Their loyalty to the secret of incest, and their consequent withholding of any kind of information from each other further contribute to the erosion of trust among all the family members. Shepard's family, as Opipari notes, is "doomed to dysfunction because their silence only reinforces their shame. Closed systems are prone to disorder because they are 
resistant to change in spite of the dysfunction surrounding them.” (125).

Once again, we arrive at the importance of language and linguistic signification in Lacan's theories, which is crucial for our final critical review of the play. Language for Lacan is like the Trojan horse: a "dangerous gift" which "offers itself to our use free of charge, but once we accept it, it colonizes us" (Žižek, 1999). As the subject is effectively castrated and is inserted in the symbolic order, he becomes colonized by language, since his insertion in the symbolic sets to motion the never-ending chain of signification and the substitution of objet $a$ for the lack. "The effect of the relationship [between ego and the other] is to open a gap that alienates the subject from his/her image" (Glowinski, Zita, \& Sara, 2001). This gap is an essential component for the operation of the symbolic relations. As Lacan explains, "without this gap that alienates him from his image, this symbiosis with the symbolic in which he constitutes himself as subject to death, could not have occurred" (Ecrits 196).

Apropos of Lacan's theory, since Tilden is not castrated, or since there has been an accident in the symbolic register, he is not subject to death. It should not be taken that he is immortal, but he is rather "undead" in the precise sense of the Hollywood zombie horror movies. Lacan refers to the other as a place where the subject is constituted as a signified. With the foreclosure of the gap between subject and the other, the subject loses an essential, defining signifier - namely, the signifier of the Name-of-the-Father.

This quality of being undead takes the form of a hereditary curse in the play, a curse that is handed down from one generation to another. Dodge exemplifies the father who, as in one of Freud's most famous dreams, doesn't know he's dead. Tilden tries to escape his fate. He goes to desert and loses his language: "He returns and his language is restored, but so, too, is his inheritance. It is not a link he can break. He is trapped again" (Bigsby, 2002). Similarly, Vince tires to escape but as he does, he sees his reflection on the windshield turning into his father's face turning into his grandfather's face turning to faces he does not know but still recognizes:

I could see myself in the windshield... I studied my face... As though I was looking at another man. As though I could see his whole race behind him. Like a mummy's face. I saw him dead and alive at the same time. In the same breath... And then his face changed. His face became his father's face. Same bones. Same eyes. Same nose. Same breath. And his father's face changed to his Grandfather's face. And it went on like that. Changing... Then it all dissolved. Everything dissolved. (130)

Here, what Vince's final aria signifies is that there is really no escape from family. Lacan believes that "[t] he subject is born insofar as the signifier emerges in the field of the Other" (Pluth, 2007). Following Lacan's theory of subject, Catherine Mathelin claims that a child could be recognized as its parents' symptom. That is, the construction of the subject as meaning precedes the actual birth of the individual. There is usually already a chain of signifiers ("a sea of language," as Lacan says) existing for a child before he or she is born. One manifestation of this theme is in the names parents give to their children. Lacan holds that, "If something is a proper name, it is inasmuch as it is not the meaning of the subject that it brings with it, but something that is of the order of the mark applied in some way to the object, superimposed on it" Pluth (2007). There is no escape from the family, because there is no escape from the names parents give to their children; or more accurately, there is no escape from the already established signifiers. In his insertion in the symbolic, the child as a signifier can only signify through the Other's gaze. The Other, or the ego ideal, is no one but the father himself. Since Dodge, as already discussed, is the embodiment of the failure of paternal metaphor, Tilden, and consecutively Vince, inherits the same obscene signifier. Similarly, Dodge is the living father; he has to die in order to return as his name to establish his law, but this curse prevents it, because Dodge is eventually incarnated in Vince. Halie's very final speech to Dodge (in fact Vince, who, as the stage direction informs us, has held the same inert position on the sofa as the dead Dodge near him) is the ultimate manifestation of this theme, as it suggests the circularity of the curse.

\section{Conclusion}

This study explored Sam Shepard's Buried Child in the light of Lacanian psychoanalysis. Apropos of Lacan's theory of psychosis, it showed how the psychotic is not initiated into the symbolic order where there are laws - social laws, particularly the incest taboo - but, due to the malfunction of the Oedipus complex, is imprisoned in the imaginary where the other, if not totally being suspended, is obscenely impaired. Dodge's incompetence in serving Tilden as a correct example along with, and intensified by, Halie's perplexing and muddling attitude toward Tilden result in a state where the son becomes his "parents' symptom," an alienated being with an unresolved complex who is destined to carry an inherited burden which critics refer to as "hereditary curse" in Shepard's plays.

\section{References}

Adler, T. P. (2002). Repetition and regression in the curse of the starving class and buried child. The Cambridge companion to Sam Shepard. Ed. Matthew Roudané. Cambridge: Cambridge University Press.

Bigsby, C. W. E. (2002). Born injured: The theatre of Sam Shepard. The Cambridge Companion to Sam Shepard. Ed. Matthew Roudané. Cambridge: Cambridge University Press.

Bigsby, C. W. E. (2004). Modern American drama, 1945-2000. Cambridge: Cambridge University Press.

Carveth, D. L. (1997). The borderline Dilemma in Paris, Texas: Psychoanalytic approaches to Sam Shepard. PSYART: A hyperlink journal for the psychological study of the arts, article 971001. [Accessed, December 8, 1997]. 
Clum, J. M. (2002). The classic Western and Sam Shepard's family sagas. The Cambridge Companion to Sam Shepard. Ed. Matthew Roudané. Cambridge: Cambridge University Press.

Evans, D. (1996). An introductory dictionary of lacanian psychoanalysis. London: Routledge.

Frazer, S. J. G. (1993). The golden bough: A study in occult and religion. Hertfordshire: Wordsworth Edition Ltd.

Glowinski, H., Zita, M. M., \& Sara, M. (2001). A compendium of lacanian terms. New York: Free Association Books.

Homer, S. (2005). Jacques Lacan. London: Routledge.

Jameson, F. (1991). Postmodernism or the cultural logic of late capitalism. Durham: Duke University Press.

Opipari, B. (2010). Shhhhhhame: Silencing the family secret in Sam Shepard's buried child. Style, 44(1), 123-138.

Pluth, E. (2007). Signifiers and acts: Freedom in Lacan's theory of the subject. Albany: State University of New York Press.

Rosen, C. (1993). Emotional territory: An interview with Sam Shepard. Modern Drama, 36(1), 1-11.

Žižek, S. (1999). The Ticklish subject: The absent center of political ontology. London: Verso.

Žižek, S. (2007). How to read Lacan. New York: W. W. Norton \& Company. 